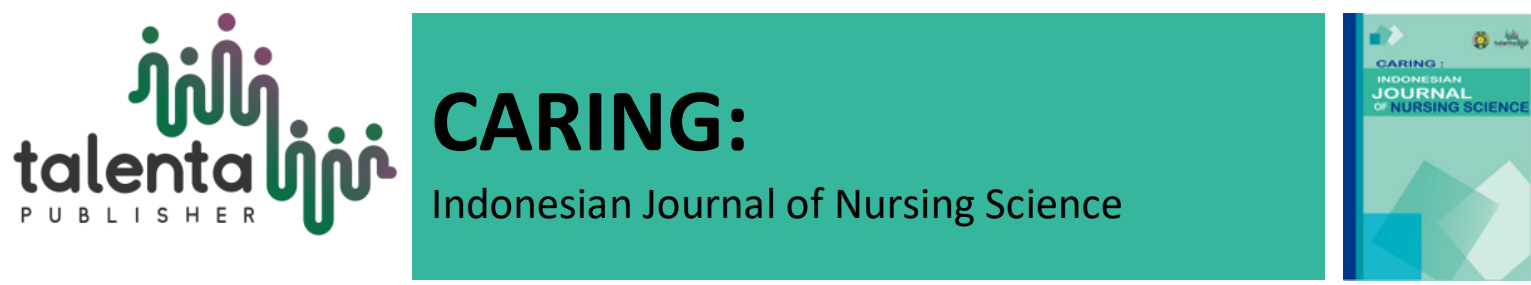

\title{
Factors Affecting The Main Hypertension Events in The Bukong Pandu Raya Village, West Kalimantan
}

\author{
Eligia Nawi' ${ }^{1}$, G. Sri Redjeki², Fulgensius Surianto ${ }^{3}$ \\ ${ }^{1,2,3}$ Institute of Health Sciences Sint Carolus, Jakarta
}

\begin{abstract}
Hypertension contributes to 9.4 million deaths from cardiovascular disease each year. The cause of hypertension are many people have for life style have a poor lifestyle, do not maintain a diet and frequently eat foods with marinated and fatty. The purpose of this research was to determine the Factors Affecting Hypertension Genesis Bukong Hamlet Village Pandu Raya West Kalimantan in 2018. This study used quantitative methods and the correlation descriptive design with cross sectional approach with 197 respondents as a sample. Result found the majority of respondents have a level of knowledge related to hypertension (62.9\%), more than half have a good lifestyle (58.4\%), revenue above average salary (57.9\%) and more than half had hypertension (54.9\%). Therefore has a significant relationship between the level of knowledge $(\mathrm{p}$ value $=0.000)$, lifestyle $(\mathrm{p}$ value $=0.000)$ and income $(\mathrm{p}$ value $=$ 0.047 ) and the incidence of hypertension. Knowledge, lifestyle and family income in the hamlet of the village Bukong Pandu Raya has a significant association with hypertension, so that health workers are expected to continue to provide support and motivation to the people to keep improving knowledge and a healthy lifestyle.
\end{abstract}

Keyword: Knowledge, Lifestyle, Income, Hypertension

Received 08 October 2019 | Revised 29 December 2019 | Accepted 29 December 2019

\section{Introduction}

Hypertension is a cardiovascular disease that has a contribution of 9.4 million deaths each year (WHO, 2013).. Hypertension was defined as systolic pressure over $140 \mathrm{mmHg}$ and diastolic blood pressure over $90 \mathrm{mmHg}$, based on two measurements or more Smeltzer, S.C., Bare, B.G., Hankle,J.L. \& Cheever, K.H (2013). Blood pressure is the force used by the blood against the walls of arteries and is measured in mmHg so can value by increased and decreased in one day. Decreased blood pressure during sleep and rise on waking, panic, breathless, and so on (Yunita Indah Prasetyaningrum, 2014). The things that can affect the increase in blood pressure are heredity, salt consumption, age and sex, obesity (overweight), stress, alcohol consumption, etc.

\footnotetext{
*Corresponding author at: Jl. Prof.Maas No. 03 Kampus USU, Medan, Indonesia.

E-mail address: gsriredjeki@yahoo.com
} 
WHO (2014) states that there are around 600 million people with hypertension worldwide, with the highest prevalence occurring in Africa by $30 \%$ while the lowest prevalence is in the American region by $18 \%$.

The Republic of Indonesia Ministry of Health (2013) states that the incidence of hypertension in Indonesia obtained by measurement at $\geq 18$ years of age is $25.8 \%$, the highest in Bangka Belitung (30.9\%), followed by East Kalimantan (29.6\%), Java West (29.4\%), Gorontalo (29.0\%), Central Sulawesi (28.7\%), West Kalimantan (28.3\%), Central Kalimantan (27.7\%), North Sulawesi (27.1\%), South Kalimantan (26.7\%) and West Papua (16.8\%). The prevalence of hypertension in Indonesia obtained through a questionnaire diagnosed by health workers is $9.4 \%$, diagnosed by health workers or taking medicine is $9.5 \%$. So, there is $0.1 \%$ who take medication themselves. Respondents who had normal blood pressure but were taking hypertension medication by $0.7 \%$.

According to the Health Profile of West Kalimantan (2013), the incidence of hypertension in West Kalimantan obtained by shaving through the age of 18 years is $28.3 \%$. According to the Sanggau District Health Office (2015 - November 2018) the incidence of hypertension in Sanggau District has increased in 2015 with 3557 people having hypertension, 4113 in 2016, 5001 in 2017 and from 2018 to November as many as 5462 person. According to the Central Damai Health Center (2015-2018) the incidence of hypertension in Parindu District in 2015 was 401 people, in 2016 there were 697 people, in 2017 there were 617 people and in 2018 there were 907 people.

The results of research conducted by Miftahul Jannah, et al (2017) about the analysis of the causes of hypertension in the working area of the Mangasa Puskesmas Tamalate Makassar district, stated that the factors associated with the incidence of hypertension were gender $(p$ value 0.001 ), age ( $\mathrm{p}$ value 0.002 ), stresss ( $\mathrm{p}$ value 0.003 ), smoking ( $\mathrm{p}$ value 0.002 ). This type of research is a quantitative study with cross sectional approach, with a sample of 50 respondents. Pandu Raya village is in the target area Puskesmas Peace Center Village in the Village According Polindes Pandu Raya (2015-2018), the incidence of hypertension in the hamlet Bukong Pandu Raya village in 2015 as many as 43 people, in 2016 as many as 47 people in 2017 as many as 52 years in 2018 as many as 58 people.

Based on interviews with both the Polindes officers and the local community, the people in Bukong Village, Pandu Raya Village have a lifestyle where people cook their own food and rarely buy ready-made dishes. Most of the people work as oil palm farmers, because they are busy working in the gardens that they have, they rarely exercise. If there are community problems in the Bukong sub-village, they rarely share their problems with other people and if there are major problems, first of all it is solved by family, if it cannot be solved by family, then it will be resolved according to custom. Most people in Bukong Hamlet have a bad habit of 
consuming excessive alcohol and many people in Bukong Hamlet smoke, especially men. The purpose of this research is to find out what factors influence the incidence of primary hypertension in Bukong Hamlet, Pandu Raya Village, West Kalimantan.

\section{Methods}

This research is a quantitative research with a correlative descriptive design with cross sectional approach that aims to find the relationship between the independent variables and the dependent variable, in this study to determine the factors that influence the incidence of primary hypertension in Bukong Village, Pandu Raya Village, West Kalimantan. The population in this study were people aged $\geq 18$ years to $\leq 60$ years, amounting to 390 people in the Bukong Hamlet, Pandu Raya Village. By using the Slovin formula, a total sample of 197 people was obtained and the sampling technique was random sampling. So that the characteristics of the sample do not deviate from the population, then before taking the sample the inclusion and exclusion criteria are determined. Data is collected from December 2018 to January 2019.

The instruments in this study consisted of the first 3 parts namely the respondent's identity, the second part was the question of knowledge about hypertension and the third part was the question of lifestyle. For the incidence of hypertension, measured based on systole data using a blood pressure gauge that has been rethought. Data were analyzed using Kendall's Tau b statistical test and Kendall's Tau c.

\section{Result}

Table 1. Frequency Distribution of Respondents Based on Knowledge in Bukong Hamlet, Pandu Raya Village, West Kalimantan

\begin{tabular}{lcc}
\hline \multicolumn{1}{c}{ Knowledge Level } & $\mathrm{N}$ & Presentation \\
\hline Good & 124 & $62,9 \%$ \\
Enough & 40 & $20.3 \%$ \\
Less & 33 & $16.8 \%$ \\
\hline Total & 197 & $100 \%$ \\
\hline
\end{tabular}

(Source: Primary data that have been processed)

Table 2. Frequency Distribution of Respondents by Lifestyle in Bukong Hamlet, Pandu Raya

\begin{tabular}{lcc}
\multicolumn{3}{c}{ Village, West Kalimantan } \\
\hline Lifestyle & $\mathrm{N}$ & Presentation \\
\hline Well & 115 & $58.4 \%$ \\
Not good & 82 & $41.6 \%$ \\
\hline Total & 197 & $100 \%$ \\
\hline \multicolumn{4}{l}{} & (Source: Primary data that have been processed)
\end{tabular}

Table 3. Frequency Distribution of Respondents Based on Income in Bukong Village, Pandu Raya Village, West Kalimantan

\begin{tabular}{lcc}
\hline \multicolumn{1}{c}{ Family Income } & $\mathrm{N}$ & Presentation \\
\hline High & 114 & $57.9 \%$ \\
Low & 83 & $42.1 \%$ \\
\hline Total & 197 & $100 \%$ \\
\hline
\end{tabular}


(Source: Primary data that have been processed)

Table 4. Frequency Distribution Based on Occurrence of Hypertension in Bukong Hamlet, Pandu Raya Village, West Kalimantan

\begin{tabular}{lcc}
\hline \multicolumn{1}{c}{ Genesis Hypertension } & $\mathrm{N}$ & Presentation \\
\hline Normal & 27 & $13.7 \%$ \\
pre Hypertension & 62 & $31.5 \%$ \\
Hypertension Level 1 & 48 & $24.4 \%$ \\
Hypertension Level 2 & 60 & $30.5 \%$ \\
\hline Total & 197 & $100 \%$ \\
\hline
\end{tabular}

(Source: Primary data that have been processed)

Table 5. Relationship between Knowledge Level and Primary Hypertension in Bukong Hamlet, Pandu Raya Village, West Kalimantan

\begin{tabular}{lcccccc}
\hline \multirow{2}{*}{ Knowledge } & \multicolumn{2}{c}{ Event } & \multicolumn{2}{c}{ Hypertension } & \multirow{2}{*}{ Total } & \multirow{2}{*}{ Score } \\
\cline { 2 - 5 } & Normal & pre HT & HT T1 & HT T2 & & \multirow{2}{*}{ N\% } \\
\cline { 2 - 5 } & $\mathrm{N} \%$ & $\mathrm{~N} \%$ & $\mathrm{~N} \%$ & $\mathrm{~N} \%$ & $\mathrm{P}$ \\
\hline Good & 2419.4 & 5443.5 & 3326.6 & 130.5 & 124100 & \\
Enough & 25.0 & 820.0 & 717.5 & 2357.5 & 40100 & \multirow{2}{*}{0,000} \\
Less & 13.0 & 00.0 & 824.2 & 2472.7 & 33100 & \\
\hline Total & 2713.7 & 6231.5 & 4824.4 & 600.5 & 197100 & \\
\hline
\end{tabular}

(Source: primary data that has been processed)

Table 6. Relationship between Lifestyle and Primary Hypertension in Bukong Hamlet, Pandu Raya Village, West Kalimantan

\begin{tabular}{|c|c|c|c|c|c|c|}
\hline \multirow{3}{*}{ Lifestyle } & \multicolumn{2}{|c|}{ Event } & \multicolumn{2}{|c|}{ Hypertension } & \multirow{2}{*}{ Total } & \multirow[b]{2}{*}{ Score } \\
\hline & Normal & pre HT & HT T1 & T2 HT & & \\
\hline & N\% & N\% & N\% & N\% & N\% & $\mathrm{P}$ \\
\hline Well & 2017.4 & 4539.1 & 3227.8 & 1815.7 & 115100 & \multirow{3}{*}{0,000} \\
\hline Not good & 78.5 & 1720.7 & 1619.5 & 4251.2 & 82100 & \\
\hline Total & 2713.7 & 6231.5 & 4824.4 & 6030.5 & 197100 & \\
\hline
\end{tabular}

Table 7. Genesis Family Income Relationship With Hypertension Hamlet Village Bukong Pandu Raya West Kalimantan

\begin{tabular}{|c|c|c|c|c|c|c|}
\hline \multirow{3}{*}{$\begin{array}{l}\text { Family } \\
\text { Income }\end{array}$} & \multicolumn{2}{|c|}{ Event } & \multicolumn{2}{|c|}{ Hypertension } & \multirow{2}{*}{ Total } & \multirow{2}{*}{ Score } \\
\hline & Normal & pre HT & HT T1 & T2 HT & & \\
\hline & $\mathrm{N} \%$ & N\% & N\% & $\mathrm{N} \%$ & N\% & $\mathrm{P}$ \\
\hline High & 1210.5 & 3228.1 & 3228.1 & 3833.3 & 114100 & \multirow{3}{*}{0,047} \\
\hline Low & 1518.1 & 3036.1 & 1619.3 & 2226.5 & 83100 & \\
\hline Total & 2713.7 & 6231.5 & 4824.4 & 6030.5 & 197100 & \\
\hline
\end{tabular}

(Source: primary data that has been processed)

\section{Discussion}

In table 1 it can be seen that the majority (62.9\%) of 197 respondents have a good level of knowledge. Table 2 shows that the majority of respondents $115(58.4 \%)$ had a good lifestyle. Table 3 shows that most respondents (57.9\%) have incomes above minimum wages work Sanggau. Table 4 shows that as many as 30.0\% of respondents had level 2 hypertension with systole $\geq 160$ and some $24.4 \%$ of respondents had level 1 hypertension with cystole 140-159. Table 5 shows that respondents who had good knowledge had more blood pressure at normal levels and pre hypertension (62.9\%). For respondents whose knowledge of hypertension was at a sufficient and insufficient level, more were those whose blood pressure was at the levels of 
hypertension 1 and 2. (75\% for sufficient knowledge and 96.9\% for insufficient knowledge). The results of statistical tests using the second test or $\mathrm{c}$ obtained $\mathrm{p}$ value: $0,000(<0.05)$ which means the hypothesis is accepted. This proves that there is a relationship between the level of knowledge with the incidence of primary hypertension in Bukong Hamlet, Pandu Raya Village, West Kalimantan.

This research is in line with research conducted by Dwi Lestari, 2017 with the title "Factors Related to the Occurrence of Hypertension in Informal Sector Workers in Yogyakarta Beringharjo Market" with the result that there is a relationship between the level of knowledge with hypertension sufferers with a value of $p=0.011$. There is a good level of knowledge because there is information that respondents get from health workers

Notoadmojo (2014) revealed that there are six levels of knowledge namely knowing, understanding, application, analysis, synthesis and evaluation. The opinion of researchers that the level of knowledge of respondents in Bukong Village, Pandu Raya Village is not only at the level of knowing and understanding but also that some have already entered at the application level. At this level the respondent has the ability to apply what has been obtained, besides the respondent knows and understands the respondent also applies in his actions to prevent and carry out routine blood pressure checks.

Table 6 shows that respondents who have good lifestyles, have more blood pressure at normal levels and pre hypertension (56\%) and respondents with poor lifestyle have more blood pressure at hypertension levels 1 and 2 at 70.7\%. Statistical test results using the second test $\mathrm{t}$ or $\mathrm{b}$ obtained $\mathrm{p}$ value $=0,000(\mathrm{p}<0.05)$ which means the hypothesis is accepted. This proves that there is a lifestyle relationship with the incidence of primary hypertension in Bukong Hamlet, Pandu Raya Village, West Kalimantan.

This study is in line with research conducted by Eltanina (2017) with the title "The Relationship Between Knowledge and Lifestyle with Hypertension in Depok 2 Chess Depok Condong Sleman Puskesmas" which states that there is a significant relationship between lifestyle with the incidence of hypertension with $\mathrm{p}$ value $=0.000$.

Rahmawati (2012) revealed that lifestyle is the most important factor that greatly influences people's lives. Unhealthy lifestyles, can cause hypertension, for example: food, physical activity, stress, and smoking. The factors that influence lifestyle are divided into two factors, namely factors from within (internal) and factors from outside (external). Internal factors include: attitudes, experiences, personality, self-concept, and motives and perceptions. The external factors include reference groups, family, social class, and culture. The habit of staying up late or irregular sleep patterns can also cause high stress, so that it can affect blood pressure 
and lack of exercise can also be a buildup of fat which will clog the blood flow resulting in increased blood pressure.

Based on the results of the study, researchers assume that with the support of good knowledge, most of the lifestyles of the people in the Bukong hamlet have a good lifestyle because respondents are aware of a good lifestyle that they can avoid from various diseases, one of them is hypertension while some respondents have less lifestyle good because respondents often do not keep eating patterns and respondents often eat salted and fatty foods, some of the respondents especially those who smoke and often stay up late and drink liquor.

Table 7 illustrates that of 197 respondents with high incomes (above MSE), with blood pressure level 1 and level 2 hypertension at $61.4 \%$ while respondents with low income, more normal blood pressure and pre hypertension by $36.1 \%$. Statistical test results using the second test $\mathrm{t}$ or $\mathrm{b}$ obtained $\mathrm{p}$ value $=0.047$ means $\mathrm{p}$ value $<0.05$ which means the hypothesis is accepted. This proves that there is a relationship between income and the incidence of primary hypertension in Bukong Hamlet, Pandu Raya Village, West Kalimantan.

Unlike the research conducted by Rizka, 2015 with the title "Risk Factors Related to the Occurrence of Productive Age Hypertension (25-54 Years)" with the results stating that there was no hypertension relationship between family income ( $\mathrm{p}$ value $=0.531$ ). According to Green (2008). The level of family income will affect one's lifestyle and how to obtain health care if there is a sick family..

Based on the foregoing, researchers assume that respondents who earn more from MSEs are more flexible in terms of determining lifestyle choices and influencing the diet and consumption of food provided. From the observations of the researchers, it was also obtained data that people who have good socioeconomic tend to have bad habits that consume excessive alcohol and many people in Bukong Hamlet smoke, especially men, so they tend to have high blood pressure

\section{Conclusion}

Researchers conducted a study entitled Factors Affecting Primary Hypertension in Bukong Hamlet, Pandu Raya Village, West Kalimantan and this study was conducted in December 2018 - January 2019 to 197 respondents in the Bukong Hamlet, Pandu Raya Village. The results of the study can be concluded as follows:

1. The frequency distribution based on knowledge of the respondents in the hamlet Bukong Pandu Raya Village West Kalimantan, from most of the 197 respondents 124 (62.9\%) of respondents have good knowledge. 
2. The frequency distribution is based on the lifestyle of respondents in the hamlet Bukong Pandu Raya Village West Kalimantan, from most of the 197 respondents 115 (58.4\%) of respondents have a good lifestyle.

3. The frequency distribution based on income respondents in Hamlet Bukong Pandu Raya Village West Kalimantan, from most of the 197 respondents 114 (57.9\%) of respondents have income / high opinion.

4. The frequency distribution Bukong incidence of hypertension in the hamlet village of West Kalimantan On Pandu Kingdom, found that of 197 respondents most respondents have normal blood pressure as much as 27 (13.7\%), pre-hypertension were 62 (31.5\%), hypertension level 1 as much as $48(24.4 \%)$ and hypertension rate of 2 to $60(30.5 \%)$.

5. There is a relationship between the level of knowledge with primary hypertension incidence in Hamlet Bukong Pandu Raya Village West Kalimantan with p value $=0.000$ ( $\mathrm{p}<0.05$ ).

6. There is a relationship between lifestyle with primary hypertension incidence in Hamlet Bukong Pandu Raya Village West Kalimantan with $\mathrm{p}$ value $=0.00(\mathrm{p}<0.05)$.

7. There is a relationship between income / opinions with primary hypertension incidence in Hamlet Bukong Pandu Raya Village West Kalimantan with p value $=0.047$ ( $<<0.05)$.

\section{Suggestions}

1. It is expected that the government and local health services can provide support and facilitate the community to increase knowledge both internally and externally by conducting health education, distributing leafleats, and organizing activities in the community to reduce the risk of hypertension..

2. Seeing the results of this research, it is expected that researchers can then examine other factors of the causes of primary hypertension by using experimental methods and other factors, thus the incidence of hypertension can be handled well in people's lives.

\section{REFERENCES}

[1] Eltanina. (2017). Hubungan Antara Pengetahuan dan Gaya Hidup dengan Hipertensi di Puskesmas Depok 2 Condong Catur Depok Sleman. https://journal.gunabangsa.ac.id

[2] Kemenkes, RI. (2013). Pusat Data dan Informasi Kementrerian Kesehatan RI. http://www.depkes.go.id/resources/download/laporan/kinerja/lak-kemenkes2013.pdf

[3] Lestari, D. (2017). Faktor-Faktor Yang Berhubungan Dengan Kejadian Hipertensi Pada Pekerja Sektor Informal Di Pasar Beringharjo Kota Yogyakarta. http://Digilib.Unisayogya.Ac.Id/2689/1/1610104364_Dwi\%20lestari_Naspub.Pdf

[4] Miftahul, Jannah,et al. (2017) tentang analisa factor penyebab kejadian hipertensi di wilayah kerja puskesmas mangasa kecamatan tamalate Makassar. HYPERLINK"https://journal.unismuh.ac.id/index.php/pena/article/view/983"https ://journal.unismuh.ac.id/index.php/pena/article/view/983

[5] Notoatmodjo. (2014). Ilmu Perilaku Kesehatan. Jakarta: PT Rineka Cipta. 
[6] Nurarif, A. H. (2015). Aplikasi Asuhan Keperawatan Berdasarkan Diagnosa Medis \& Nanda NIC-NOC. Jogjakarta: Mediaction.

[7] Prasetyaningrum, Y. I. (2014). Hipertensi Bukan Untuk Ditakuti. Jakarta: FMedia. HYPERLINK"https://books.google.co.id/books?id=8uluBgAAQBAJ\&lpg=PP1\&d $\mathrm{q}=$ hipertensi\&hl=id\&pg=PP1"ll"v=onepage \&q=hipertensi\&f=false" https://books. $g$ oogle.co.id/books?id=8uluBgAAQBAJ\&lpg=PP1\&dq=hipertensi \&hl=id\&pg=PP $1 \# v=$ onepage $\& q=$ hipertensi $\& f=$ false

[8] Profil Kesehatan Kalimantan Barat. (2013). Prevalensi Hipertensi. Https://Dinkes.Kalbarprov.Go.Id/Wp-Content/Uploads/2018/08/Profil-KesehatanKalimantan-Barat-Tahun-2013.Pdf

[9] Smeltzer, S.C., Bare, B.G., Hankle,J.L. \& Cheever, K.H (2013). Keperawatan Medikal Bedah. (12, Ed.) Jakarta: EGC. 